1. Home

2. Journals

3. International Journal of Energy Sector Management

4. Volume 14 Issue 2

5. Analysis of an optimal hybrid power system for an off-grid community in Nigeria

\title{
Analysis of an optimal hybrid power system for an off-grid community in Nigeria
}

Olubayo Moses_Babatunde,_Damilola Elizabeth_Babatunde_ Iheanacho Henry_Denwigwe_, Toyosi Beatrice_Adedoja__Oluwaseye Samson_Adedoja_Taiwo Emmanuel_Okharedia International Journal of Energy Sector Management

ISSN: $1750-6220$

Publication date: 4 November 2019

Abstract

Purpose

This study aims to analyze the effects of variations in annual real interest rates in the assessment of the techno-economic feasibility of a hybrid renewable energy system (HRES) for an off-grid community.

Design/methodology/approach

Hybrid Optimization of Multiple Energy Resources (HOMER) software is used to propose an HRES for Abadam community in northern Nigeria. The HRES was designed to meet the basic needs of the community over a 25-year project lifespan. Based on the available energy resources in the community, photovoltaic (PV), wind turbine, diesel generator and battery were suggested for integration to serve the load requirements. 
Findings

When the annual real interest rates were taken as 10 and 8 per cent, the total amount of total energy fraction from PV, wind turbine and the diesel generator is 28,57 and 15 per cent, respectively. At these interest rates, wind turbines contributed more energy across all months than other energy resources. The energy resource distribution for $0,2,4$ and 6 per cent annual real interest rates have a similar pattern, but PV contributed a majority of the energy.

Practical implications

This study has used annual real interest and inflation rates dynamic behavior to determine optimal HRES for remote communities. Hence, its analysis will equip decision-makers with the necessary information for accurate planning.

Originality/value

The results of this study can be used to plan and design HRES infrastructure for off-grid communities around the world.

\section{Keywords}

- Energy production

- Optimization

- Wind-PV

- Cash flow

- HOMER

- Hybrid renewable energy 
- Net present cost

\section{Citation}

Babatunde, O.M., Babatunde, D.E., Denwigwe, I.H., Adedoja, T.B., Adedoja, O.S. and Okharedia, T.E. (2019), "Analysis of an optimal hybrid power system for an off-grid community in Nigeria", International Journal of Energy Sector Management, Vol. 14 No. 2, pp. 335-357. https://doi.org/10.1108//JESM-012019-0009

Download as .RIS

\section{Publisher}

:

Emerald Publishing Limited

Copyright $\odot$ 2019, Emerald Publishing Limited

Related articles

1. How can a low-income household procure small-scale hybrid renewable energy system?

Olubayo Moses Babatunde et al., International Journal of Energy Sector Management, 2019

2. A comprehensive methodology for setting up rural electrifications with minimum budgets on indigenous villages in Malaysia

Kok Yew Soon et al., International Journal of Energy Sector Management, 2019

3. Techno-economic analysis of hybrid system (PV/wind/diesel generator/grid) for domestic consumers in balochistan (nokkundi \& ormara)

Irfan Khan Niazi et al., World Journal of Engineering, 2015

1. Intelligent hybrid power generation system using new hybrid fuzzy-neural for photovoltaic system and RBFNSM for wind turbine in the grid connected mode

Alireza REZVANI et al., Frontiers in Energy, 2016

2. Predictive Biosciences Launches Bladder Cancer Test on PGM, Plans WGS-Based Test 
GenomeWeb, 2012

3. Aperiodic tidal data resource assessment and LCOE analysis of selected areas in Nigeria

L M Amoo, Clean Energy

2021 Emerald Publishing Limited 